\title{
Correction to: Causal Sufficiency and Actual Causation
}

\section{Sander Beckers ${ }^{1}$}

Published online: 28 August 2021

(C) Springer Nature B.V. 2021

\section{Erratum to: J Philos Logic \\ https://doi.org/10.1007/s10992-021-09601-z}

The original version of this article unfortunately contained editing mistakes in the text body, such as unnamed references and misnumbered Theorems. All mistakes have now been corrected.

Publisher's Note Springer Nature remains neutral with regard to jurisdictional claims in published maps and institutional affiliations.

The online version of the original article can be found at https://doi.org/10.1007/s10992-021-09601-z

Sander Beckers

srekcebrednas@gmail.com

1 Munich Center for Mathematical Philosophy, LMU Munich, Münich, Germany 